УАK 338.2:338.

T. Lozova,

doctor of economic sciences, professor, professor department of economy and humanities Odessa

National Academy of Telecommunications O.S. Popova

ORSID ID: 0000-0003-3244-408X

H.Oliinyk,

doctor of economic sciences, docent, head of the department of marketing Open International University

of Human Development "Ukraine"

ORSID ID: 0000-0002-4073-4012

A. Bielova,

doctor of Economics, Associate Professor, Department of Economics and Management of the GSP

"Institute of Innovation Education" of Kyiv National University of Construction and Architecture

ORCID: 0000-0003-4106-7351

A. Al-Tmeizi,

Ph.D. Deputy Director of the Institute of Economics and Management of the Open International

University of Human Development "Ukraine"

ORCID: 0000-0002-8266-2010

DOI: $10.32702 / 2306-6806.2019 .4 .18$

\title{
FEATURES OF FORMATION OF THE COMPANY STATUTE CAPITAL: RIGHT TO USE INTANGIBLE ASSETS AS A PROPERTY CONTRIBUTION TO THE AUTHORIZED CAPITAL
}

\author{
T. І. Аозова, \\ А. е. н., професор, професор кафедри економіки та гуманітарних наук, \\ Одеська національна академія зв'язку імені О.С. Попова \\ Г. Ю. Олійник, \\ А.е.н. Аоцент, завідувач кафедри маркетингу, Відкритий міжнародний університет розвитку Аюдини "Україна" \\ A. I. Белова, \\ А. е. н., Аоцент, професор кафедри економіки та менеджменту, \\ ВСП "Інститут інноваційної освіти" Київського національного університету будівництва і архітектури \\ А. Ю. Аль-Тмейзі, \\ к. е. н., заступник директора, Інститут економіки та менеджменту \\ Відкритого міжнародного університету розвитку Аюдини "Україна"

\section{ОСОБАИВОСТІ ФОРМУВАННЯ СТАТУТНОГО КАПІТАЯУ ПІАПРИЕМСТВА: ПРАВО КОРИСТУВАННЯ НЕМАТЕРІАИЬНИМИ АКТИВАМИ ЯК МАЙНОВИЙ ВНЕСОК АО СТАТУТНОГО КАПІТААУ}

Business in the digital world is a complete rethinking of traditional approaches to working with clients, creating unique experiences, a new perspective on partnership and competition, and, of course, new business strategy models that will be embodied in the daily activities of companies and their structural divisions - in operational model. For Ukraine, which is planning a course on Eurointegration, the goal is to create conditions for joining the community of European developed countries and attract investment through the creation of joint ventures and other largescale internal transformation of enterprises. For this process, an important component of business in the digital world is the clear formation of all components of the company's authorized capital.

At the moment, the world stands on the verge of large-scale transformations. This is under the influence of new digital technologies: there are multidimensional changes both at the global level and at the level of states, industries, industries, corporations (hereafter, companies) and people themselves. Companies change both externally and from the middle. External transformation introduces a new concept for working with clients, partners and contractors. At this stage, it is not enough to meet the expectations of the client, they must be able to predict, and his requirements grow day by day. A significant number of top-managers'surveys around the world show that the time-to-market withdrawal period, rather than months or years as before, is one of the most difficult tasks of the present [1].

The new concept does not work on operating management and operating models because for the work in the digital world, companies need to rebuild themselves entirely from the middle and start with the need for a clear formation of their charter capital, which was not paid attention to corporatization. because at that time there was the task of rapid transformations. fast corporatisation without preparation for transformation. That is how Ukrtelecom and Ukrposhta joint stock companies were created. "Ukrzaliznytsia", as a state-owned enterprise, started to prepare for corporatization as early as 2007. Such training stages were conducted in 2010, 2012 , and 2014. 
For Ukrtelecom, as for a company that does not have state ownership, and which plans to attract foreign investment, it is necessary to conduct a qualified inventory of all balance sheet items and form its authorized capital taking into account the requirements of the system digitalization and the inclusion in the authorized capital of the value of intangible assets in the first section of the Balance Sheet - "Non-current assets", which will increase the cost of the authorized capital of the company by an average of 80-120 percent. The new concept will not work on existing management and operating models, and for work in the digital economy, the company needs to rebuild itself from the inside. This is necessary because the traditional model of business development in Ukrtelecom, as in our country (management system and operating model of the company), is mainly static, oriented towards slow and gradual development. Rapid response to changes in it is restrained by significant barriers laid down in the very nature of such a model:

- Traditional vertical business culture and decision-making system. Such a model is characterized by a hierarchical control system, formalized processes, regulations and instructions, and a rigid KPI system for organizational units and employees. In the daily activities involved a large number of people who constantly perform monotonous and routine operations. Significant forces and resources in this model are spent on internal control; to control the implementation of the system of operational business processes;

- The complexity of traditional automated corporate systems is the main obstacle to the introduction of new strategies in a modern company;

- The traditional model for innovation and change management, which is based largely on the Project Management Body of Knowledge (PMBoK), a traditional project methodology. In developmental processes, it is a record of the achieved consistency in the technical tasks, testing and passing programs, again, the necessary approvals.

Бізнес У цифровому світі - це повне переосмислення традиційних підходів до роботи з кАіснтами, створення унікальногодосвіду, новий погляд на партнерство и конкуренцію, та, безумовно, нові моделі бізнесстратегій, які знайдуть Своє втілення У щоденній діяльності компаній та їх структурних підрозділів - в операційній моделі. Аля України, яка планує курс на Євроінтеграцію, метою є створення умов Аля входження до спільноти Європейських розвинених країн та залучення інвестицій шляхом створення спільних підприємств та інших масштабних внутрішніх перетворень підприємств. Аия цього процесу важливою складовою бізнесу у цифровому світі $\epsilon$ чітке формування всіх скАадових статутного капіталу компанії.

Наразі світ стойть на порозі масштабних перетворень. Це відбувається під впливом нових цифрових технологій: іАуть багатомірні зміни як на глобальному рівні, так і на рівні держав, індустрій, гал узей, корпорацій (далі, компаній) та самих Аюдей. Компанії змінюються як зовнішньо, так і з середини. Зовнішня трансформація впроваджує нову концепцію по роботі з кАієнтами, партнерами та контрагентами. На цьому етапі недостатньо відповідати чеканням кАієнта, їх необхідно вміти передбачити, а його вимоги з кожним днем ростуть. Значна кількість опитувань топ-менеджерів компаній по всьому світу показує, що термін виводу продукту або послуги на ринок (time-to-market) дні, а не місяці або роки, як раніше, і це є однією із самих важких задач Сьогодення [1].

Нова концепція не запрацює надіючих управлінських і операційних моделях, бо дяя роботи у цифровому світі компанії повинні перебудувати себе повністю з середини, і почати необхідно з чіткого формування Свого статутного капіталу, якому при корпоратизації не було приділено уваги, тому що на той час стояла задача швидких перетворень, швидкої корпоратизації без підготовки до перетворень. Саме так було створено акціонерні товариства "Укртелеком"та "Укрпошта". "Укрзалізниця", як державне підприємство, процес підготовкидо корпоратизації почала проводитище з 2007 року. Такі етапи підготовки буди проведені У 2010, 2012 та 2014 роках.

Аля "Укртелекому"якдля компанії, у якої немаєдержавної власності і яка планує залучення іноземних інвестицій, необхідно провести кваліфріковано інвентаризацію всіх статей балансу та сформувати свій статутний капітал із врахуванням вимог цифровізації системи та вкАючення до статутного капіталу вартості нематеріальних активів уперший розділ Балансу 一 "Необоротні активи", щодозволить підвищити вартість статутного капіталу компанії в середньомуна 80-120 відсотків. Нова концепція не запрацює на існуючих управлінських і операційних моделях, аАля роботи у цифровій економіці компанії необхідно перебудувати себе із середини. Це необхідно, тому що традиційна модель побудови бізнесу в "Укртелекомі", як і в нашій державі (система управління та операційна модель компанії), в основному, статична, орієнтована на повільний поступовий розвиток. Швидке реагування на зміни в ній Стримуються значними бар'єрами, закАаденими в саму природу такої моделі:

— традиційна вертикальна культура ведення бізнесу і система прийняття рішень. Аля подібної моделі характерні ієрархічна система управління, формалізовані процеси, регламенти й інструкції, жорстка система КРІ Аля організаційних одиниць і працівників. Ао щоденної діяльності залучено значну кількість Аюдей, які постійно виконують одноманітні та рутині операції. Значні сили та ресурси в такій моделі витрачаються на внутрішній контроль; на контроль за виконанням системи операційних бізнес-процесів;

- СкАадність традиційних автоматизованих корпоративних систем - цеосновна перешкода впровадження нових стратегій у сучасній компанії; 
- традиційна модель впровадження нововведень та управління змінами, яка в основному спирається на традиційні проектні методології на основі РМВоК (Project Management Body of Knowledge). Упроцесах розвитку - це фіксування, досягнутих узгодженостей в технічних завданнях, програмах випробувань та проходження зновунеобхідних узгоджень.

Key words: intangibles, legal and accounting aspects, normative documents, accounting, standards: national and international.

Ключові слова: статутний капітал, нематеріальні активи, правові та облікові аспекти, норлативні документи, бухгалтерський облік, стандарти бухгалтерського обліку: начіональний іміжнародний.

\section{FORMULATION OF THE PROBLEM}

The development of digital technologies provides the company with new opportunities and tools that will help overcome artificial barriers created by man's traditional business models and allow them to bring it to the next level. The authors of the study of authorized capital of joint-stock companies Ukrtelecom, Ukrposhta and Ukrzaliznytsya show that they did not include the value of intangible assets. Therefore, we consider it necessary to provide a methodology for determining, recording, valuing and valuing intangible assets (which are not material, but have value and play an important role in the entity's operations, and can be identified) to the article "Intangible assets assets "of the Balance and to the authorized capital of the company as its important component in restructuring the company and preparing it for attracting foreign investors.

\section{ANALYSIS OF LAST RESEARCHES AND PUBLICATIONS}

An intangible asset is a non-monetary asset that is nonmaterial and can be identified [2, p. 4]. In defining the same term as in paragraph 8 of IAS 38, a "substance" is indicated instead of "form". There are no other differences, therefore, the definition of the term in international and Ukrainian standards can be considered identical.

From the definition of the term, it is clearly possible to distinguish three properties, the presence of which allows one or the same object to be classified as assets: nonmonetary; immateriality; the possibility of identification.

Nonmonetary and intangible assets make it possible to distinguish intangible assets, respectively, from financial and material assets. These properties are understandable and generally do not cause problems. Otherwise, there is a case of identification. The Accounting Standard (Accounting Standard 8) does not even have a hint of how to understand the expression "asset can be identified". Well, as in many other cases, we turn to the International Accounting Standard 38 [\$12], from which one can understand that identification is the ability to distinguish an object from among other objects $[\$ 11$ International Accounting Standard 38]. The acquired or acquired intangible asset is recognized in the balance sheet if there is a probability of future economic benefits associated with its use, and its value can be reliably determined [Accounting Regulation (Standard) 8, paragraph 6].

Such an object of accounting, as an intangible asset, is probably one of the contradictory elements of the modern economy.

Not surprisingly, eminent financial reporting researchers note the following: "Despite the fact that managers act within the framework of generally accepted accounting principles, one can confidently say that even two of them do not account for intangible assets alike". It is also true that none of them does not account for all their intangible assets alike.

The nature of intangible assets is that information about them is relevant, although not very reliable, even in the sense of reliability for users of financial reporting [ 3 p.156].

The notion of "intangible assets" is well known not only to accountants. It is known to marketers, financiers, economists, and anyone who for one reason or another has to read and analyze financial statements. This is exactly the case - "Intangible assets" is referred to as one of the balance sheet items (line codes: $1000 ; 1001 ; 1002)$. Moreover, intangible assets, as one of the types of accounting objects, are devoted to separate standards: national - Accounting (accounting) standard 8 "Intangible assets" and international - International accounting standard 38. Special norms dealing with intangible assets are in the tax and economic codes, as well as in other regulatory documents. But expertsanalysts and professionals-practitioners point to the serious difficulties that arise when working with intangible assets. More precisely, difficulties arise up to the beginning of work - when it becomes necessary to determine its asset in general and intangible assets in particular. This arises because the object is invisible and does not always have documents on it, and their circle is quite wide. The accounting of intangible assets is conducted for each object in groups specified in item 5 of the Standard (accounting) 8 [2].

How to protect, evaluate, sell, take into account what you can not see, try, weigh what you can not touch? What does not have a material form but has value and plays an important role in the activities of business entities, and in the life of all mankind? What is called the rights to the result of intellectual labor in the theory of law, and intangible assets in the theory of accounting?

Finding answers to the questions was not easy. But we tried to decompose complex concepts into simple components and outlined guidelines that would help the specialists:

- from the many manifestations of intellectual property objects, identify those that need to be recognized in the register;

- proceeding from the method of obtaining an economic effect, and not only from traditions, to classify objects of accounting;

- digitization of intangible assets, their coding and entering into the Balance Sheet and the Authorized Capital.

After reviewing the analytical materials of this article, the specialists will no longer have to go through a difficult way of recognizing the objects of intangible assets, they will only have to reflect capital investment, because it is profitable, reliable, evaluating them. Computer programs and a trademark - these are the main aspects of accounting for intangible assets in virtually all Ukrainian enterprises. The accounting of intangible assets practically in the analyzed companies is not carried out in such groups as: the right to use the property (the right to use the land plot, in accordance with the land legislation, the right to use the building, the right to lease premises); rights to industrial property objects (the right to inventions, commercial secrets, know-how, copyright, programs). The answers to these questions are reflected in this study.

The purpose of this article is to improve the management of intangible assets as an integral part of accounting in making them into the authorized capital of the company, which makes it possible to increase it by $70-$ 80 percent.

\section{MAIN RESULTS OF THE STUDY}

Public Joint-Stock Company Ukrtelecom (hereinafter referred to as Ukrtelecom) is one of the largest companies 
in Ukraine, which has a long history and uses innovative technologies, provides a full range of telecommunication services in all regions of the country.

Ukrtelecom has a particularly strong position in the market of services to the Internet and fixed telephony. Ukrtelecom is a leader in the market of high-speed fixed access to the Internet and holds leading positions in the market of fixed telephony.

Ukrtelecom has created the most powerful national data transmission trunk network in Ukraine, built on the basis of modern technology DWDM, which allows consumers to provide modern telecommunication services in all settlements of Ukraine.

These technological innovations are not only basic assets, but also intangible assets that are rights to the result of intellectual work in the theory of law and intangible assets in the theory of accounting, but these rights are not taken into account in the company's authorized capital. Such work is legally determined by Art. 177 of the Civil Code of Ukraine, which states that "objects of civil rights are things, including ... property rights, results of works, services, results of intellectual, creative activity, information, as well as other tangible and intangible assets" [4]. In this case, "the thing is the subject of a tangible asset, in respect of which there may be civil rights and obligations" [4, st. 179].

In fact, this is what financial services call tangible assets [2]. Although not every thing can be an independent material asset, since the legislator has also identified such a concept as "property".

Property, as a "special object is considered a separate thing, a set of things, as well as property rights and obligations" [4, tbsp. 190]. That is, a separate unit of property (one tangible asset) can consist of several or many things. For example, a property complex with a plot of land, buildings, structures, equipment, etc.

The property rights of this property complex are determined, evaluated, drawn up and are an intangible asset that should be reflected in the accounting system and the Company's Balance Sheet in the asset. As we see, in the context of this article, the legislator referred to property, as well as property rights.

In practice, under the property rights understand the subjective rights of participants in the legal relationship that relates to the possession, use and disposal of property, as well as with the material requirements that arise in relation to the distribution and exchange of property $[5 ; 6]$.

However, the list of property rights is not limited to the classic triad of powers (possession, use, disposal). Property rights can also be called the right: economic management [4, tbsp. 136]; the right to operational control [4, items. 137]; the right to lease (hire, operational leasing); the right to permanent use of land - the right to own and use [4, tbsp. 92]; servitude - limited right to use someone else's immovable property; superficies - the contract based on the right to use another's land for development [4, tbsp. 424].

These are very important issues, because the subjects of legal relationships may be different property rights, which have different values and are differently reflected in the Founder's contract, the balance sheet and the authorized capital of the entity. Usually, it is believed that the owner of the property has the most right, which owns, uses and disposes of the property belonging to him. However, the owner may have fewer rights, transferring, say, the property to the lease, he voluntarily, and for a certain period, deprives himself of the right to own and use the property. Different volumes of rights depend on the established right [8, p. 163$255]$ and its value.

What can I contribute to the authorized capital? In accordance with the Law of Ukraine "On Business Associations" [5, ct. 13] "contributions to the authorized (compounded) capital of an economic partnership may be money, securities, other things or property, or other alienation of rights having a monetary valuation, unless otherwise provided by law". A similar rule is contained in part two of Art. 115 of the Civil Code of Ukraine [4].

Alienation of property rights of intellectual property is not limited, therefore they can be a contribution to the authorized capital. However, even if it is clear that what property rights can be introduced into the statutory capital, and which ones, they may still have problems, for example, in the case of attracting foreign capital, liquidation of the company. Particularly clear in the documents should be defined and assessed ownership of land as an intangible asset [2]. The experience of joint stock companies Ukrtelecom and Ukrzaliznytsya shows that clear ownership rights increase the currency of the balance of "intangible assets" by $70-80$ percent [7].

The legislator on 06.02.2018 adopted the new Law of Ukraine "On Limited Liability Company", which came into force on 17.06.2018 (hereinafter Law 1). One of the innovations of this Law was the narrowing of the responsibilities of members of the society [8]. In accordance with Article 6 of the Law1, members of a partnership are obliged to adhere to the statute and comply with the decisions of the general meeting, while they may have duties established by law and the charter of the partnership [8].

Instead, art. 117 of the Civil Code of Ukraine, along with the above responsibilities of the members of the company, establishes the obligation to fulfill its obligations to the company, including those related to property participation, as well as to make deposits in the amount, in order and the means provided for by the constituent documents and not to disclose commercial information about the activities of the company.

It is difficult to understand the reason for such innovations. Provision of the norms of the current Law of Ukraine "On Business Associations" [5] may lead to abusive practices by unscrupulous participants. After all, for the stable work of the partnership, a clear balance must be struck between the rights and obligations of its participants.

As the case law shows, the absence of a balance between rights and obligations at the legislative or institutional level makes it impossible to protect the rights of the participants and the society as a whole, against the activities of unscrupulous participants, which ultimately leads to corporate conflicts and the blocking of the company's activities [7].

The legislator Law 1 reduced the requirements to the contents of the statute and identified only three items that must necessarily be in the statute: full and abbreviated (if any) the name of the partnership; the management bodies of the company, their competence, the procedure for their decision, the procedure for joining the partnership and the exit from it [8].

Legal uncertainty on the important aspects of corporate relations can lead to legal disputes and make it impossible for the company to operate. For example, in the statute, after the entry into force of the Law 1 , it is not necessary to enter information about the members of the partnership and the size of the shares that they own, and therefore, it will not be necessary to change the statute in the event of changes in the composition of participants and/ or the size of their shares.

Consequently, there is a potential risk of unlawful change in the members of the company. By the way, the Final and Transitional Provisions of the Law 1 provide for amendments to Art. 17 of the Law of Ukraine "On the State Registration of Legal Entities, Individuals of Entrepreneurs and Public Formations" in the part of the state registration of changes in the information on the size of the authorized capital, the size of the shares in the authorized capital or the composition of the members of the partnership. However, at the date of writing this article, such changes to the specified law have not been made.

Quite a difficult question is the assessment of property rights. At first glance it seems that everything is simple: as agreed and appreciated. After all, expert evaluation is not required for the most part. This is a big mistake. Certain 
criteria for evaluation still have to be. And not only so that the supervisors do not have unnecessary questions, but to protect their property and property of the enterprise.

Imagine this situation: the participant of the company made a contribution to the authorized capital - the right to use the property belonging to him, say, certain equipment, which he owns, and in six months decided to leave the company. At the same time, he requires not only to return his property, but also to pay the cost of his share in the authorized capital [8, p. 54]. And this share, exactly, is the estimated value of the right to use the equipment. It turns out that this participant can earn a good deal at the expense of his partners. This once again confirms the need to pay special attention to issues of valuation of intangible assets.

Evaluation is one of the most common, important and complex financial procedures. Possibility of reliable assessment - a mandatory and unchanging criterion of recognition of all objects of accounting without exception. As a result of evaluation, the value of the objects of accounting is determined. That cost allows you to summarize accounting information, compare the results of economic activity, etc. Without evaluation, accounting is not possible in principle. But both evaluation and cost-categories are multi-faceted and often unpredictable. That is why the decision of accounting problems with their participation a very complicated and troublesome thing. And this despite the fact that a significant part of the absolute majority of accounting standards, both international and domestic, is devoted to evaluation issues. Well, when it is necessary to evaluate such a difficult object of accounting, as intangible assets, the complexity of tasks doubles, and even tripled.

Consider the issue of evaluation conceptually and practically.

Score - conceptually. The accounting standard (8) actively uses the concept of "valuation" but does not explain its meaning, possibly considering that it is obvious and does not require explanations. However, International Accounting Standards $38(\$ 100)$ do not so consider, and "financial statements (for the Conceptual Assessment) use several different, basic, bases of assessment with varying degrees and in different combinations". These basics include:

- historical cost;

- current cost;

- cost of sale (repayment);

- Present value.

Such magnitude is due to a variety of objects of accounting and business operations. That is, every kind of value "comes into play" at a certain time and in a certain city.

Score-practically. One of the main valuation rules states: the cost varies, so any object should be periodically overestimated. There are three main points for this purpose:

- initial recognition;

- at the balance sheet date:

- at the time of the release of the object.

The second rule can be formulated as follows: methods of evaluation look in the standard - in the standard that regulates the accounting of the object.

Initial - hence, historical. Intangible assets come to the enterprise in different ways. They can be purchased for money received in exchange for other assets and free of charge and so on. And precisely because of this, according to the Regulations (standard) of accounting 8 , the order of formation of their initial value depends. And the price is formed, that is, it consists of (collected) from different elements. The question of which items should be included in the original cost, are at this stage key. It can be formulated and otherwise, which costs should be recognized as costs associated with the acquisition and production of intangible assets. In this wording, this question is relevant for tax accounting.

"Initial cost" - historical (actual) cost of non-current assets in the amount of cash or the fair value of other assets paid (transferred), spent for the acquisition (creation) of non-current assets - this definition is provided in paragraph 4 of the Accounting (accounting) standard 7 "Fixed assets". However, note that it does not refer to Fixed Assets, but to Non-current Assets. Consequently, it must also be applied to intangible assets.

In addition, the formation of the initial value of intangible assets and fixed assets is very much in common. And from the above definition it follows that the initial value can be equal to:

- or the amount of money paid (payable);

- or the fair value of other transferred assets.

Or one or two. "Meet" in the cost of one object paid amount and fair value as if they should not. And it really would have been so, if not multi-elementality of the original value. As a rule, it includes the cost of the object itself (main element) and other actual costs (additional elements). The above alternative (or the amount of money, or the value of the transferred assets) relates mainly to the main element.

Consequently, during the formation of the initial cost, a combination of fair value and actual costs is possible.

Table 1 shows the order of formation of the initial value and the elements from which it is composed, depending on how the intangible assets come to the enterprise.

The concentrated information in one table clearly depicts (column V of Table 1) that the order of formation of the initial cost exceeds the limits established in the definition of this term. This applies, in particular, to clauses 13 and 14 of the Accounting Standards (Standard) 8. The most significant discrepancy is that the definition of the term refers to "... the fair value of other assets paid (transferred), spent for acquisition (creation) of non-current assets", while paragraphs 13 and 14 require the determination of the fair value of the objects received. As regards free-standing objects, this requirement is clear: the fair value of the assets transferred in return can not be determined, since they simply do not exist.

But the initial value of the objects that they make in the authorized capital, perhaps, nevertheless, should be shaped on the basis of the value of corporate rights that they convey, rather than the fair value of these objects. Although, ideally, these two values must coincide.

Special attention should be paid to the definition of elements of the original value.

Item 11 of the Accounting Standards (Standard) 8 lists the items of initial value, that is, those costs from which it is formed. In this case, with respect to the main element, that is, the amount paid to suppliers of intangible assets, there is a special clause: this amount does not include the received trade discounts.

The list of additional costs associated with the acquisition of intangible assets is much shorter than the similar list for fixed assets. And this is natural. After all, because of its specificity, intangible assets do not require, for example, the cost of delivery or installation. On the other hand, this specificity does not allow to list all possible types of additional costs in the standard. Therefore, in the list referred to in paragraph 11 of the Accounting Standards (Standard) 8, only indirect taxes and indirect taxes which are not subject to indemnity are directly named. The rest of all costs are "hidden" in the practically dimensionless group of "other expenses", directly related to the acquisition of an object and bringing it to a state in which it is suitable for intended use.

In the International Accounting Standard 38 (§ 28), information on this subject is slightly higher.

Examples of costs that can be directly attributed are:

a) expenses on employee benefits (as defined in the International Accounting Standard 19 "Employee benefits") arising directly from the bringing of the asset to working condition;

b) professional fees paid directly as a result of bringing the asset to working condition; 
Table 1. Formation of the initial value of the objects recognized as intangible assets, depending on how they are received by the enterprise

\begin{tabular}{|c|c|c|c|c|}
\hline $\begin{array}{c}\text { № } \\
\text { by order }\end{array}$ & $\begin{array}{l}\text { Method of receiving intangible } \\
\text { assets for the enterprise }\end{array}$ & $\begin{array}{c}\text { Elements of original } \\
\text { cost }\end{array}$ & Initial cost (actual cost) & $\begin{array}{c}\text { standard of accounting } \\
\text { (standard) of accounting } 8\end{array}$ \\
\hline & A & $\mathrm{B}$ & V & $\mathrm{G}$ \\
\hline 1 & The object was purchased at a cost & additional costs & $\begin{array}{l}\text { Amount of money paid (to be paid) } \\
\text { to the object provider and additional } \\
\text { services) }\end{array}$ & item 11 \\
\hline 2 & $\begin{array}{l}\text { The object was purchased in } \\
\text { exchange for a similar object }\end{array}$ & cost of the object & Less than two values: residual or fair & The first paragraph item 12 \\
\hline \multirow[t]{2}{*}{3} & \multirow{2}{*}{$\begin{array}{l}\text { The object is purchased in } \\
\text { exchange for a non-object }\end{array}$} & cost of the object & Fair value of the transferred object & \multirow[t]{2}{*}{ Second paragraph item 12} \\
\hline & & additional costs & Amount of money paid (payable) & \\
\hline 4 & $\begin{array}{l}\text { The object was purchased in } \\
\text { exchange for a non-object } 3 \text { with a } \\
\text { cash supplement }\end{array}$ & cost of the object & $\begin{array}{l}\text { The fair value of the transferred } \\
\text { object is increased (reduced) by the }\end{array}$ & $\begin{array}{l}\text { Second paragraph } \\
\text { item } 12\end{array}$ \\
\hline \multirow[t]{2}{*}{6} & \multirow{2}{*}{$\begin{array}{l}\text { The object was received as a } \\
\text { contribution to the authorized } \\
\text { capital }\end{array}$} & cost of the object & Agreed by the founders of fair value & \multirow[t]{2}{*}{ item 14} \\
\hline & & additional costs & amount of money paid (payable) & \\
\hline 7 & $\begin{array}{l}\text { The object was obtained as a result } \\
\text { of the merger of enterprises }\end{array}$ & cost of the object & Fair value & item 15 \\
\hline \multirow[t]{2}{*}{8} & \multirow{2}{*}{$\begin{array}{l}\text { The object has been purchased } \\
\text { along with other objects paid for } \\
\text { by the total amount }\end{array}$} & cost of the object & \multirow{2}{*}{$\begin{array}{l}\text { The amount paid is distributed in } \\
\text { proportion to the fair value of each } \\
\text { item }\end{array}$} & \multirow[t]{2}{*}{ item 16} \\
\hline & & additional costs & & \\
\hline 9 & $\begin{array}{l}\text { The object was created by the } \\
\text { enterprise }\end{array}$ & cost of the object & Actual cost & item 17 \\
\hline
\end{tabular}

c) the cost of checking the proper functioning of such an asset.

In addition, the initial cost includes direct labor costs, depreciation of equipment, and any other costs provided by the Accounting Standards (Standard) 16

Between the research and development of Ukrtelecom, which creates intangible assets on its own, one should understand the differences between research and development. In accordance with the Accounting Regulation (Standard) 8, research costs "are recognized as expenses of the reporting period during which they were incurred, without recognizing such costs in the future Intangible asset". Some types of expenses, in order not to emerge the temptation to capitalize them, are listed in clause 9 of the Accounting Standards (Standard) 8, marked "not recognized as intangible assets" and indication "are to be reflected as part of the reporting period in which they were executed".

This list includes:

- research costs;

- expenses for training and retraining of personnel;

- expenses on advertising and promotion of products on the market;

- costs for the creation, reorganization and transfer of an enterprise or a part thereof;

- costs for improving the business reputation of the enterprise, the cost of publications and the cost of creating trademarks (trademarks).

The list, albeit clear in general, nevertheless leads to certain reflections.

First, somewhat embarrassed by its "closed" character, that is, the lack of reservations such as "etc". Such lists are considered to be exhaustive, which could mean, in relation to this situation: only intangible assets that are included in the list are not recognized as intangible assets. Hence, all other costs should be recognized as such. But such a statement is simply absurd, which, incidentally, is confirmed by the International Accounting Standard 38. As in many other cases, it is the international standard that prompts how to understand one or the other of the standard of the national standard. Paragraph 69 of the International Accounting Standard 38 contains a list that is very similar to the above. However, it follows from the accompanying text that examples of costs are given in the list.

Secondly, for all types of expenses listed in clause 9 of the Accounting Regulation (Standard) 8, only one is decoded through the definition of the relevant term. In accordance with Clause 4 of the above-mentioned standard, "research is the research planned by the enterprise for the first time in order to receive and understand new scientific and technical knowledge". The definition of the term in the Accounting Standards (Standard) 8 and the International Accounting Standard 38 is the same, but much more attention is paid to the research in the international standard. The research phase is devoted to a separate, albeit small, section, in which, in particular, paragraphs 56 of the International Accounting Standard 38 provide examples of studies that are appropriate to use when creating the article "Intangible assets" of the Company's authorized capital.

Special issues of valuation at the balance sheet date require the following explanations for which financial management should pay attention to.

In international standards, the expression "assessment after initial recognition" is often used. In this case, the most often refers to the assessment at the balance sheet date. In some cases, as, for example, in the Standard (Accounting Standard) 32, the clarification is given "on the date of the annual balance sheet". And this clarification is very important, because the assessment, among other things, the procedure is quite troublesome, and sometimes not expensive.

As with any other non-current assets, valuation for intangible assets is very important at the balance sheet date. After all, their real cost depends on many factors (in particular, external) and under the influence of these factors is changing. And if the real value has changed, it should be reflected in the account.

International Accounting Standard 38 proposes entities to select and consolidate as one element of accounting policy one of the two valuation methods after initial recognition:

- cost method (paragraph 74 International Accounting Standard 38);

- Revaluation method (paragraph 75 International Accounting Standard 38). 
So paragraph 74 states: "After initial recognition, an intangible asset should be measured at its cost less any accumulated depreciation and any accumulated impairment losses".

Paragraph 75 reads that "After initial recognition, an intangible asset should be reported at a revalued amount, which is its fair value at the date of the revaluation, less any subsequent accumulated depreciation and any subsequent accumulated impairment losses". For revaluation, in accordance with this Standard, the fair value should be determined by reference to an active market. Reassess the trail with sufficient regularity. In addition, for the accurate determination of book value, it is possible to use national standards for the assessment of property and property rights, certified appraisers, who will document the cost of intangible assets.

\section{CONCLUSIONS}

Intangible assets are an important component of accounting and allow you to increase the balance of the currency by $70-80 \%$, which is very important when attracting foreign investment.

Under the term "asset", the financial manager understands the resources controlled by the enterprise, the use of which is expected to lead to future economic benefits. A lawyer, marketer to understand the essence of the asset need to know its legal nature, which depends on the possibility of its use in certain legal relationships.

The right to use property should be clearly defined, including the term of use.

In assessing property rights, the term of its use should be taken into account. Obviously, the use of someone else's car for an hour and a year has a different price.

The introduction of property rights to the authorized capital must be executed not by the protocol, but by the contract (in the classical version - the founder's agreement, certified by a notary), as well as by the decision of the General meeting of shareholders. And if it is a question of making additional deposits or joining the partnership of a new participant, then you can enter into an agreement on the procedure for making a contribution to the authorized capital of the company.

In such an agreement it is obligatory to describe the consequences of the party's exit from the partnership before the end of the term of use of the property. In this case, an alternative is possible: either the property remains in the use of the partnership before the expiration of the term stipulated by the contract, or the participant who leaves the company, compensates him a certain amount (it must be determined immediately) for early repayment of the property.

The analysis of the content of Law 1 shows that there are gaps, conflicts and uncertainties, so the participants of the societies need to carefully approach the constituent documents, as they will become the only guarantee of stable economic activity of the company.

An analysis of existing regulatory legal documents and techniques on this issue, which were developed, approved and repeatedly used in Ukrzaliznytsia [11], allows us to recommend to develop, taking into account the specifics of the industry, methodological recommendations "Procedure for conducting technical inventory of objects real estate and intangible assets".

To approve the Procedure as an industry standard on the basis of which to work the inventory of the said assets and the results of inventory to be taken into account in the balance sheet and in the authorized capital of Ukrtelecom.

\section{$\Lambda$ ітература:}

1. TSS.Weekly-tss@groteck.ru-Toп-5 новостей недели с 11по15марта2019 Операционная модель бизнеса 2020, предвосхищая будущее. Александр Ильин, 13.03.2019.
2. Положення (стандарт) бухгалтерського обліку 8 "Нематеріальні активи". Чинний. - Режим доступу: http://zakon.rada.gov.ua/laws

3. Paul B.W.Miller and Paul R. Bahnson. Oualiti Financial Reporting:McGraw-Hill.-2002.-15P.263-264

4. Цивільний кодекс України від16.01.2003 р. № 4351V зі змінами. Режим доступу:http://zakon/rada/gov/ ua/laws

5. Закон України "Про господарські товариства" від 19.01.1991p. №1576-X11, з змінами. Чинний. - Режим доступу: http://zakon. rada.gov/ua/laws

6. Земельний кодекс України від 04.11.2018 № 2768111. Чинний. - Режим доступу: http//jurist-ua/net/ кодекси

7. Олійник Г.Ю. Управління нерухомістю: теорія, принципи, практика, концепція єАиного банку даних: монографія / Г.Ю. Олійник, В.А. Аяшенко, М.М. Ониськів. - К.: Аогос, 2013. - 331 с.

8. Закон України "Про товариства з обмеженою та додатковою відповідальністю" від 06.02.2018p. № 2275V111. Чинний. ВBP. 2018. № 13. - Ст. 69.

9. Воробієнко П.П. Перехідна економіка: теорія та практика: монографія/ Воробієнко П.П., Цозова Т.І.,Олійник Г.Ю. - Одеса: ОНАЗ ім. О.С. Попова, 2018. - 272 с.

10. Аозова Т.І., Олійник Г.Ю. Ціфровізація проведення технічної інвентаризації об'єктів нерухомого майна: земельних ділянок, розташованих на них будівель, споруд та передавальних пристроїв // НПЖ "Економіка та держава", № 1 січень 2019.- С. 4-9.

11. Һозова T.I., Порядок проведення технічної інвентаризації об'єктів нерухомого майна та земельних ділянок залізничного транспорту. - К.: АЕТУТ, 2007. -194 с. (затверджений наказом "Укрзалізниці" № 710Ц від 16.12.2007 р.).

\section{References:}

1. Ilyin, A. (2019), "Operating model of the business 2020, anticipating the future", available at: https:// www.tssonline.ru/ (Accessed 30 March 2019).

2. Ministry of Finance of Ukraine (1999), " Regulation (standard) of accounting 8 "Intangible assets", available at: http://zakon.rada.gov.ua/laws (Accessed 30 March 2019).

3. Miller, P.B.W. and Bahnson, P.R. (2002), Oualiti Financial Reporting, McGraw-Hill, NY, USA.

4. Verkhovna Rada of Ukraine (2003), "The Civil Code of Ukraine", available at: http://zakon.rada.gov.ua/laws (Accessed 30 March 2019).

5. Verkhovna Rada of Ukraine (1991), The Law of Ukraine "On Business Associations" available at: http:// zakon.rada.gov.ua/laws (Accessed 30 March 2019).

6. Verkhovna Rada of Ukraine (2018), "Land Code of Ukraine", available at: http//jurist-ua/net/codes (Accessed 30 March 2019).

7 Oliynyk, G.Yu. Lyashenko, V.A. and Onyski, M.M. (2013), Upravlinnia nerukhomistiu: teoriia, pryntsypy, praktyka, kontseptsiia iedynoho banku danykh [Property Management: Theory, Principles, Practice, Concept of a Single Database], Logos, Kyiv, Ukraine.

8 Verkhovna Rada of Ukraine (2018), Law of Ukraine "On Limited Liability Companies", VVR, vol.13.

9 Vorobienko, P.P. Lozova, T.I. and Oliynyk, G.Yu. (2018), Perekhidna ekonomika: teoriia ta praktyka [Transition economics: theory and practice], ONAT them. O.Popova, Odessa, Ukraine.

10. Lozova, T.I. and Oliynyk, G.Yu. (2019), "Digitalization of the technical inventory of real estate objects: land plots and buildings, structures and transmitters located on them", Ekonomika ta derzhava, vol. 1, pp.4-9.

11. Lozova, T.I. (2007), Poriadok provedennia tekhnichnoi inventaryzatsii ob'iektiv nerukhomoho majna ta zemel'nykh dilianok zaliznychnoho transportu [Procedure for conducting technical inventory of real estate objects and land plots of railway transport], DETUT, Kyiv, Ukraine.

Стаття надійлла до редакиї 04.04.2019 p. 